IRENA BOROWIK

Instytut Socjologii Uniwersytetu

Jagiellońskiego w Krakowie

\title{
SPOŁECZNE KONSEKWENCJE CHRZTU MIESZKA I I CHRYSTIANIZACJI POLSKI (O ZNACZENIU RELIGII W PRZESZŁOŚCI I DZISIAJ)
}

Sporo dyskusji i krytyki wywołały głośne tezy Samuela Huntingtona ${ }^{1}$, który zakwestionował priorytetowy charakter gospodarki i polityki w porządku światowym, i ogłosił, że to kultura i religia są fundamentem, na którym są zbudowane cywilizacje, oraz że w ich pokładach tkwi potencjał, grożący „zderzeniem”, napędzanym przez dążenie określonych cywilizacji do dominacji. W myśl scenariuszy Huntingtona złote wieki cywilizacji europejskiej, opartej na chrześcijaństwie, w nieunikniony sposób należą do przeszłości. Pomijając tu pytanie o to, czy wierzyć, czy przeciwnie, nie wierzyć w katastroficzne wizje przyszłości wziętego autora, trudno nie zgodzić się z konstatacją, że rola chrześcijaństwa, aksjologicznego fundamentu Europy ${ }^{2}$, została zakwestionowana. Wyrazem tej osłabionej pozycji religii są nie tylko puste kościoły w wielu europejskich krajach, ale przede wszystkim dyskusje wokół, ostatecznie nieuchwalonej zresztą, konstytucji Unii Europejskiej, w których kością niezgody była formuła uwzględniająca odwołanie do chrześcijaństwa. Polscy politycy - wówczas premierem był Leszek Miller, a prezydentem Aleksander Kwaśniewski, czyli przywódcy deklarujący się jako niewierzący - należeli do tych, którzy popierali wprowadzenie w preambule odniesień do znaczenia chrześcijaństwa dla kształtowania Europy. Wśród przeciwników takiego stanowiska prym wiodła Francja. Ostatecznie w odpowiednim fragmencie zapisu w preambule znalazło się ogólne odwołanie do kulturowego, religijnego i humanistycznego dziedzictwa Europy, „z którego wynikają powszechne wartości,

\footnotetext{
${ }^{1}$ S. Huntington, Zderzenie cywilizacji, Warszawa 2007 (oryg. ang. 1996).

${ }^{2}$ A.Flis, Chrześcijaństwo i Europa. Studia z dziejów cywilizacji Zachodu, Kraków 2001, s. 204.
} 
stanowiące nienaruszalne i niezbywalne prawa człowieka, jak również wolność, demokracja, równość oraz państwo prawne" ${ }^{3}$, ale tradycje religijne nie zostały nazwane i chrześcijaństwo w zapisie się nie pojawiło. Tym samym rola chrześcijaństwa w kształtowaniu Europy i życia Europejczyków nie znalazła uznania.

Czemu chrześcijaństwo zawdzięcza swoje wcześniejsze sukcesy? ${ }^{4}$ Czy potrzeby, na które odpowiadało, są dzisiaj nieaktualne? Co stanowiło o konkurencyjnej sile nowej religii? Co skłaniało wyznawców pierwszych wieków do konwersji, a władców do przyjmowania nowej wiary? Jakie wartości wniosło chrześcijaństwo w dzieje Polski i jakie jest jego dziedzictwo z dzisiejszej perspektywy? Wreszcie - jakie jest współcześnie znaczenie katolicyzmu i Kościoła rzymskokatolickiego dla polskiego społeczeństwa i Polski?

Nie tyle przyjęcie chrześcijaństwa (konieczność historyczna była oczywista - można było to zrobić wcześniej lub później, ale nie mogła Polska pozostać enklawą kultów pogańskich), ile przyjęcie go w obrządku łacińskim oznaczało trwałe wpisanie się w polityczny porządek świata. Poprzez chrzest Mieszko I włączył polskie ziemie do zachodniego świata, cywilizacji kontynuującej dziedzictwo Rzymu, w opozycji do Bizancjum. Rozłam w chrześcijaństwie, usankcjonowany w 1054 r., oznaczał nie tylko określone polityczne koneksje, ale także wpływał na rozwój kultury i mentalności społecznej, ufundowanej na religii. Znaczenie tej odmienności szczególnie wzrastało, jak twierdzi na przykład Jerzy Kłoczowski, począwszy od XII w., kiedy to jego zdaniem różnice między chrześcijaństwem wschodnim i zachodnim zaczęły się pogłębiaćs.

W Polsce cechy łacińskiej tradycji w chrześcijaństwie okazały się szczególnie istotne w okresie rozbiorów i w dekadach konfrontacji z komunizmem. Silna pozycja Kościoła rzymskokatolickiego, znakomita organizacja, niezależność od świeckich władz oraz powiązania z Watykanem, a także identyfikacja ogółu Polaków z katolicyzmem znacząco przyczyniły się do zachowania tożsamości narodowej i integracji społecznej. Utrwalił się w tych trudnych okresach splot tego, co narodowe i katolickie. Kościół rzymskokatolicki był reprezentantem społeczeń-

${ }^{3}$ Dziennik Urzędowy Unii Europejskiej, C 310 z 16 XII 2004, s. 3.

${ }^{4}$ Stawiał sobie to pytanie z socjologicznej perspektywy m.in. Rodney Stark. Za ważną przyczynę powodzenia uznał on postępowy charakter nowej religii, a przede wszystkim dowartościowanie kobiet, co jego zdaniem stało się jedną z głównych przyczyn szybkiego rozpowszechniania się chrześcijańskich idei. Por. R. Stark, The Rise of Christianity: How the Obscure, Marginal Jesus Movement Became the Dominant Religious Force in the Western World in a Few Centuries, San Francisco, Calif. 1997.

${ }^{5} \mathrm{~J}$. Kłoczowski, Młodsza Europa. Europa Środkowo-Wschodnia w kręu cywilizacji chrześcijańskiej, Warszawa 1998, s. 291. 
stwa politycznego, pozbawionego podczas zaborów siły organizującej w postaci państwa, a w okresie okupacji hitlerowskiej i późniejszej konfrontacji z komunizmem - pozbawionego podmiotowości i możliwości wyłaniania własnych reprezentacji. To nie był przypadek, że w okresach kryzysów politycznych właśnie Kościół reprezentował społeczeństwo, walcząc nie tylko o swoje prawa, ale o prawo do wolności. Te funkcje - kompensacyjne, można powiedzieć - szczególnie widoczne były w okresie solidarnościowego zrywu i po ogłoszeniu stanu wojennego, kiedy to Kościół niósł pomoc rodzinom aresztowanych, pozbawionych pracy i środków do życia dysydentom politycznym i ich rodzinom, ale także stwarzał przestrzeń wolności dla sił o zróżnicowanej orientacji, zaangażowanych w walkę z komunizmem. Wówczas, co ciekawe i niepowtarzalne, Kościół rzymskokatolicki łączył w sobie dwie niezwykłe cechy - powszechność z jednej strony, bazującą na ludowym modelu manifestacji pobożności, a z drugiej - otwartość na środowiska intelektualne niekoniecznie utożsamiające się z religią i Kościołem w wymiarze osobistym, a nawet otwarcie deklarujące niewiarę, ale zaangażowane w opozycyjną działalność 6 . W ten unikalny sposób Kościół w Polsce w owym czasie był jednocześnie i tradycyjny, i otwarty, co przyczyniało się do jego niekwestionowanego ogólnospołecznego autorytetu, osiągającego w latach osiemdziesiątych XX w. maksymalne wskaźniki, dodatkowo wspieranego charyzmą Jana Pawła II. Katolicyzm, religijna wiara powiązana z rozumieniem polskości, przeszłości i wyobrażeń o przyszłości, wsparte stabilną instytucją Kościoła rzymskokatolickiego, stały się elementem procesu kształtowania się społeczeństwa obywatelskiego.

Podniesione w ostatnim akapicie kwestie zasługują na rozwinięcie. Wspomniałam o typie historycznie ukształtowanej i umacnianej formy religijności społeczeństwa polskiego, określając ją mianem ludowej.Jej cechy szczegółowo opisywał Stefan Czarnowski, podkreślając między innymi przywiązanie do rytuałów (tj. większe znaczenie czynności religijnych niż wierzeń, w tym bardzo ważny społecznie kult patronów, świętych, odpusty, pielgrzymki, kapliczki, integrujące wspólnotę na poziomie lokalnym i ogólnonarodowym), powiązanie ze zwyczajami, bezrefleksyjność wierzeń, brak mistycyzmu, parafię jako wspólnotę integrującą zbiorowość, a rolę księdza jako jej przywódcy, przy jednoczesnej obecności elementów magicznych w światopoglądzie i przekonaniu, że Polacy są bardziej niż inne narody zespoleni z Bogiem i Kościołem.

\footnotetext{
${ }^{6}$ Por. A. Michnik, Kościót. Lewica. Dialog, Warszawa 2009.

${ }^{7}$ S. Czarnowski, Kultura religijna wiejskiego ludu polskiego, w: idem, Dzieła, t. 1, Warszawa 1956, s. 88-107.
} 
Czarnowski charakteryzował w ten sposób stosunek do religii i funkcje Kościoła rzymskokatolickiego, mając na myśli przede wszystkim chłopów. Jednak, jak się wydaje, cechy te bardzo mocno się zakorzeniły w mentalności ogółu Polaków, a wspomniane wyżej okoliczności historyczne sprzyjały ich dalszemu utrwalaniu. Szczególnie istotne było to po 1945 r., kiedy, pomijając kwestie ideologii, miały miejsce gwałtowne przemiany społeczne. Przed wojną dwie trzecie Polaków zamieszkiwało wieś - po jej zakończeniu wielu z nich migrowało do miast, by uczestniczyć w ich odbudowie albo w zagospodarowaniu Ziem Odzyskanych. Możliwość zdobycia wykształcenia oznaczała awans społeczny i przeniesienie się do miasta na stałe. Rozwijał się przemysł, kobiety się emancypowały, ale wszystkie te tak rewolucyjne zmiany nie odbiły się równie gwałtownie na popularnym modelu religijności. Badania prowadzone przez socjologów w różnych środowiskach, wiejskim i miejskim, w rozmaitych grupach, takich jak inteligencja, nauczyciele, a nawet wśród studentów i młodzieży, w latach sześćdziesiątych, siedemdziesiątych i później, ku niezadowoleniu decydentów ukazywały powszechność przywiązania do religii w Polsce - zupełnie zresztą inaczej niż na przykład w byłym Związku Radzieckim i wielu innych krajach tzw. bloku wschodniego. Jednocześnie socjologowie podkreślali, że o ile spotykamy się z bardzo licznymi deklaracjami przynależności Polaków do katolicyzmu i Kościoła rzymskokatolickiego (Władysław Piwowarski określił ten wymiar jako płaszczyznę ogólnonarodową), o tyle w odniesieniu do wiary i moralności mamy do czynienia z daleko posuniętym zróżnicowaniem. Wspomniany wyżej zasłużony socjolog religii tę drugą płaszczyznę określił jako codzienną, a w jednym ze swoich tekstów, mając na myśli rozdźwięk pomiędzy wysoką liczbą deklaracji przynależności do Kościoła i katolicyzmu a selektywnością w akceptacji prawd wiary i norm moralnych, określił polskich katolików jako „nieświadomych heretyków”.

$\mathrm{Na}$ ogólnonarodowej płaszczyźnie religijności, manifestującej się nie tylko w identyfikacji z katolicyzmem, ale także we wspominanym już rytualizmie i innych cechach religijności ludowej w okresie konfrontacji z komunizmem, podobnie jak w okresie rozbiorów, społeczeństwo integrowało się jako całość. Ta spoistość narodowo-wyznaniowa ma swoje konsekwencje. Ceną masowości jest niska refleksyjność wiary, nieznajomość innych religii, niska wiedza religijna (na przykład dla niektórych trzy osoby Trójcy Świętej to Jezus, Matka Boska i Bóg Ojciec) i ogólny brak zainteresowania teologią oraz słabe powiązanie wiary z normami moralnymi (na przykład oszustwa podatkowe nie należą do kategorii grzechu). Model socjalizacji utrwala te cechy. Religijność Polaków - kiedyś określona przez ks. Józefa Majkę jako „katechizmowa” (czyli wyposażona w najbardziej rudymentarne zasoby) - kształtowana jest w pro- 
cesie szkolnej edukacji religijnej przez Kościół i przez określony model wdrażania do religii w rodzinie, nastawionej przede wszystkim na przekazywanie obowiązku praktyk i kontrolowanie ich regularności. Utracony pluralizm - wielokulturowość, zróżnicowanie narodowe i religijne charakterystyczne jeszcze dla Polski w przededniu II wojny światowej wiążą się z dominującym typem religijności. Mniejszości religijne w Polsce stanowią 2-3\% i są rozproszone, zatem większość Polaków w miejscu zamieszkania, sąsiedztwie, w pracy i rodzinie rzadko doświadcza bezpośrednich relacji z wyznawcami religii innych niż katolicyzm. Utwierdza to istniejące stereotypy i ma wpływ na wiedzę nie tylko o tych innych religiach, ale także o własnej, gdyż kontakt z odmiennością wyzwala konieczność głębszych samookreśleń i je ułatwia.

Co ciekawe, 25 lat transformacji ustrojowej spowodowało pewne przesunięcie akcentów - ale w skali ogólnokrajowej ilościowo nieznaczne, chociaż zapewne znaczące w perspektywie długofalowej. W transformację społeczeństwo polskie wkraczało z bardzo wysokimi wskaźnikami deklaracji: identyfikacji z katolicyzmem (95\%), wiary w Boga (ponad 90\%), zaufania do prymasa Józefa Glempa jako głowy polskiego Kościoła (w styczniu 1990 r. ponad 89\%) ${ }^{8}$ i do Kościoła rzymskokatolickiego jako instytucji (niemal 75\%) ${ }^{9}$. Wielu socjologów, wśród nich pisząca te słowa, przewidywało wówczas, że w warunkach demokracji moga na polu religijnym w Polsce następować zmiany podobne do tych, które wcześniej zaszły w Hiszpanii, a później także we Włoszech i Irlandii, czyli, ujmując rzecz krótko - dojdzie do spadku znaczenia religii i poziomu religijnego zaangażowania. Tak jednak się nie stało, pomijając znaczne wahania zaufania społecznego do Kościoła w latach dziewięćdziesiątych. I to jest właśnie fascynujące - trwałość nastawień religijnych pomimo rewolucyjnych w swej istocie zmian we wszystkich w zasadzie obszarach życia społecznego. Czym tę trwałość tłumaczyć? Można widzieć kilka równie prawdopodobnych i niekoniecznie wykluczających się wyjaśnieńn ${ }^{10}$. Ale najważniejsze wydają się dwa. Po pierwsze - rozpad starego świata i budowanie nowego dla większości stanowiły i dla wielu dalej stanowią doświadczenie nasycone traumą. W tych okolicznościach

${ }^{8}$ Raport CBOS ze stycznia 1990 r., Aprobata działalności i zaufanie do przedstawicieli życia publicznego kraju w styczniu 1990 roku. Komunikat z badań, 〈http://www.cbos.pl/ SPISKOM.POL/1990/K_007_90.PDF> (dostęp: 12 XII 2014).

${ }^{9}$ Raport CBOS z lutego $1990 \mathrm{r}$., Świat instytucji politycznych $w$ świadomości społecznej, styczeń 1990 rok. Komunikat z badań, 〈http://www.cbos.pl/SPISKOM.POL/1990/K_ 010_90.PDF> (dostęp: 12 XII 2014).

${ }_{10}$ Por. I. Borowik, Why Has Religiosity in Poland not Changed sinced 1989? Five Hypoteses, „Politics and Religion” 3, 2010, 2, s. 262-275. 
religia integrowała społeczeństwo jako całość, ponad rosnącymi i nieakceptowanymi nierównościami i zagrożeniami dnia codziennego ${ }^{11}$, podobnie jak w przeszłości, w okresach zaborów czy konfrontacji z komunizmem. Zatem trwałość postaw religijnych można wiązać z reprodukcją pewnego, określonego i utrwalonego sposobu radzenia sobie przez polskie społeczeństwo z doświadczeniem kolejnej traumy. Po drugie - transformacja wpisała się dobrze także w wypracowane strategie działania Kościoła jako obrońcy ładu, autorytetu w sytuacji braku równowagi, bezpiecznej teraźniejszości i wizji przyszłości.Z tej perspektywy następujące po 1989 r. zmiany stanowiły dla Kościoła kolejne wyzwanie, na które zareagował on w taki sam sposób jak w przeszłości.

Z dzisiejszej perspektywy jednak, po ćwierćwieczu przemian, coraz bardziej widoczne jest to, że nowe czasy wymagają nowych strategii. $\mathrm{Na}$ przykład w przeszłości polityczne zaangażowanie Episkopatu, a nawet reprezentowanie ubezwłasnowolnionego społeczeństwa politycznego, było nie tylko powszechnie akceptowane, ale stanowiło też źródło autorytetu Kościoła i przekonania, że dobrze reprezentuje żywotne interesy polskiego narodu. W warunkach demokracji jednak większość (ponad $70 \%$ badanych) te formy zaangażowania krytykuje, pomimo tego, że zaufanie do instytucji władzy, takich jak rząd, sejm czy sądownictwo, jest na bardzo niskim poziomie. Narastają podziały społeczne na tle wyobrażeń co do tego, jakie jest miejsce religii w życiu publicznym, a sam katolicyzm, uwolniony od wspólnego wroga, jest coraz bardziej zróżnicowany. Z jednej strony charyzmatyczny ojciec Tadeusz Rydzyk, Radio Maryja, „Nasz Dziennik”, Telewizja Trwam kontynuują integrację poprzez religię wokół identyfikowanych wrogów polskości - Europy, Unii Europejskiej, komunistów, masonów i Żydów ${ }^{12}$, działając tym samym na rzecz - jak to określił przywoływany wcześniej S. Czarnowski - nacjonalizmu wyznaniowego. I chociaż niektórzy lekceważąco o tym środowisku mówią, etykietując je jako „moherowe berety” i odwołując się do tego, że wśród zwolenników tej opcji dominują starsze i słabo wykształcone kobiety, to jednak wystarczy posłuchać Radia Maryja, by zauważyć, że perspektywa taka ma czynnych zwolenników wśród katolickich

${ }^{11}$ Pippa Norris i Ronald Inglehart, na podstawie analizy wyników badań z 80 krajów, wykazali istotny związek pomiędzy poziomem religijności i bezpieczeństwa socjalnego. Zależność układa się we wzór: im wyższe bezpieczeństwo tym niższa religijność. Polska na skali bezpieczeństwa plasuje się nisko, podobnie jak między innymi Meksyk. W obu tych i innych podobnych krajach wskaźniki religijności należą do najwyższych.

12 Por. Czego nas uczy Radio Maryja? Socjologia treści i recepcji, red. I. Krzemiński, Warszawa 2009; E. Bobrowska, Obrazowanie społeczeństwa w mediach. Analiza radiomaryjnego dyskursu, Kraków 2007. 
elit, profesorów Katolickiego Uniwersytetu Lubelskiego i niektórych biskupów. I stanowi poważną siłę, kształtującą poglądy wielu Polaków na temat tego, co jest dobre dla kraju, a co złe, co należy popierać, a z czym walczyć. Z drugiej strony rozwijają się wspólnoty charyzmatyczne, które proponują zupełnie inną wersję katolicyzmu, opartą na wewnętrznym przeżyciu bardziej zindywidualizowanej wiary i traktującą chrześcijaństwo jako swoistą drogę życia swoich członków. Po przeciwległej stronie „,szkoły” ojca Rydzyka plasuje się także katolicyzm otwarty, którego symbolicznym przewodnikiem jest „Tygodnik Powszechny”, szanujący myślących inaczej i udostępniający owym ,innym” swoje łamy, nastawiony proekumenicznie. Jak te krańce mają się do tzw. ogółu Polaków?

Biorąc pod uwagę rozmaite badania socjologiczne, zarówno sondaże prowadzone przez wyspecjalizowane ośrodki, takie jak Centrum Badania Opinii Społecznej czy Ośrodek Badania Opinii Publicznej (obecnie: TNS Polska), jak i celowe badania socjologów religii, można widzieć trzy zasadnicze kategorie katolików w Polsce: kulturowi, gorliwi i nominalni. Jakie dziedzictwo ponad tysiąca lat chrześcijaństwa w Polsce niosą w sobie te grupy? Co jest w ich obrębie ważne? Jakie znaczenie religii przypisują w wymiarze ogólniejszym, społecznym i osobistym?

Ilościowo dominują katolicy kulturowi, których za określeniem ks. Majki sprzed lat można też nazwać „niedzielnymi”, „katechizmowymi”, a których udział można szacować na co najmniej połowę wszystkich uznających się za katolików. Przywiązani są oni do rytmu religijnych świąt, udają się do kościołów na msze nie rzadziej niż raz na kilka tygodni, celebrują wielkanocną spowiedź, wierzą w Boga i Jezusa (chociaż niekoniecznie w diabła i anioły), uznają przykazania, chociaż części z nich nie odnoszą do siebie. Przyjmują księdza po kolędzie, nawet jeśli są wobec księży krytyczni. Religia jest w tej grupie czynnikiem zbiorowego samookreślenia, przypisania siebie i swojej tożsamości do kategorii katolików. Zbiorowe samookreślenie w kategoriach religijnych jest bardzo ważne, ponieważ pozwala umieścić się w określony sposób na mapie świata, tworzyć granice pomiędzy „nami” i „nimi”, będąc w ten sposób źródłem porządku i sensu. Jednocześnie religia w tej grupie nie jest osobistą, przeżywaną wartością, wyraża się w daleko posuniętej rutynizacji doświadczenia religijnego, w którym dominują ramy znaczenia nadawanego przez religię, a nie treść tych doświadczeń. Przykładowo - ramę stanowić będzie wiara w to, że Jezus Chrystus jest Synem Bożym (celebrowana na Boże Narodzenie) i że cierpiał na krzyżu (celebrowana na Wielkanoc), ale wiara ta nie jest powiązana z odniesieniem do samego siebie i do własnego zbawienia, wymagającego określonych konsekwencji w życiu codziennym i w podejmowanych działaniach lub w ich zaniechaniu z motywów religijnych. 
Ta „religia środka” jest dobrym punktem odniesienia dla dwóch pozostałych grup - jedną z nich można określić mianem katolików żarliwych, a drugą, sytuującą się po przeciwległej - katolików nominalnych. Obie można szacować na 15-20\% i obie wewnętrznie są zróżnicowane. Katolicy, których tu określam jako żarliwych, cechują się pogłębioną formacją religijną w tym sensie, że wyznawana wiara w ich przypadku niesie rozległe konsekwencje dla sposobu życia, wyznawanych wartości, podejmowanych decyzji. Wiara w Boga, Chrystusa, przykazania stanowią odniesienie zarówno dla codzienności, tego co zwyczajne, jak i nadają znaczenie wydarzeniom szczególnym, biograficznym, indywidualnym i wspólnotowym. Kilka elementów stanowi o zróżnicowaniu tej grupy - mieszczą się w niej bowiem zarówno ci, którzy bez zastrzeżeń identyfikują się z Kościołem, regularnie (czyli z częstotliwością przewyższającą średnie krajowe) uczestniczą w nabożeństwach i często też są zaangażowani w przykościelne wspólnoty, jak i tacy, którzy wobec Kościoła są krytyczni, zdystansowani, może nawet niechętni, postrzegając Kościół jako instytucję o „ziemskiej” orientacji, ale jednocześnie własne życie kształtują pod wyraźnym wpływem chrześcijaństwa. Ci pierwsi prezentują nastawienia ekskluzywistyczne, czyli przyznają wyższość własnej religii, a część z nich zapewne uznaje inne religie za „fałszywe” i „nieprawdziwe”, a Polaków niekatolików za „nieprawdziwych" Polaków. Zatem w tej kategorii znajdą się wyznawcy katolicyzmu fundamentalistycznego. Ci drudzy reprezentują tzw. katolicyzm otwarty, inkluzywny, cechują się nastawieniem ekumenicznym w stosunku do innych religii, widząc w nich wspólne cechy, takie jak dążenie do dobra czy przykazanie miłości bliźniego. Katolicy nominalni także są zróżnicowaniw tej grupie można umieścić zarówno tych, którzy określając się jako katolicy,jednocześnie deklarują, że są niewierzący,jak i tych, którzy uznają się za wierzących, ale wiara ta bardzo słabo lub wcale nie manifestuje się w ich życiu. Niezależnie jednak od tego uznają oni ważność obrzędów przejścia: chrztu, ślubu i pogrzebu, zdarza się (niektórym nigdy, niektórym raz lub kilka razy w roku), że odwiedzą kościół, a w chwili dramatycznej spróbują się pomodlić.

Ten obraz jest oczywiście uproszczony, niemniej na potrzeby niniejszej syntezy rysuje "grubą kreską" oblicze społecznej manifestacji katolicyzmu w Polsce. Z punktu widzenia socjologii nie ma "prawdziwych" i „nieprawdziwych” katolików, po prostu dzisiejsze konsekwencje przyjęcia chrześcijaństwa są zróżnicowane i w zróżnicowany sposób przejawia się ważność religii.

Warto jeszcze wspomnieć o najistotniejszych tendencjach zmiany stosunku do religii w ostatnich dekadach. Przy ogólnie zachowanych cechach ciągłości stopniowo spada poziom regularności religijnych praktyk, w tym 
w szczególności uczestnictwa w niedzielnych nabożeństwach. Wydaje się to długofalową tendencją. Spada też od jakiegoś czasu poziom powołań kapłańskich i zakonnych. Ważną przesłanką zachodzących zmian jest także obniżenie poziomu religijności młodych; w szczególności uważałabym za znaczące to, że stosunek młodych kobiet do religii upodabnia się do modelu „męskiego”, tzn. stają się one mniej religijne niż miało to miejsce w poprzednich pokoleniach. Nie są to zmiany dramatyczne, ale biorąc pod uwagę także to, że ateiści obecnie śmielej niż w innych latach manifestują swój światopogląd i walczą o swoje prawa, a także fakt, że w wielu tematach dyskutowanych publicznie, takich jak in vitro, związki partnerskie czy gender Kościół jest kontrowersyjnym aktorem, można sądzić, iż otwiera się jakaś nowa karta w historii społecznego znaczenia katolicyzmu dla Polski i Polaków. 